\title{
In-vitro Propagation of Strawberry (Fragaria $\times$ ananassa Duch.)
}

\author{
Sunita Jhajhra*, L.K. Dashora, Jitendra Singh, P. Bhatnagar, \\ Ashok Kumar and C.K. Arya
}

\begin{abstract}
Plant Tissue Culture Laboratory, Department of Fruit Science, College of Horticulture and Forestry, Jhalarapatan City, Jhalawar, India
\end{abstract}

*Corresponding author

\section{A B S T R A C T}

\begin{tabular}{|l|}
\hline K e y w o r d s \\
$\begin{array}{l}\text { Propagation, in-vitro, } \\
\text { Fragaria, Nodal } \\
\text { segments, Adenine } \\
\text { sulphate, MS medium }\end{array}$ \\
\hline Article Info \\
\hline $\begin{array}{l}\text { Accepted: } \\
\text { 24 September } 2018 \\
\text { Available Online: } \\
\text { 10 October } 2018\end{array}$ \\
\hline
\end{tabular}

\section{Introduction}

Strawberry (Fragria $\times$ ananassa Duch.), a fruit that features a fragrantly sweet flavor, is the most widely consumed berry fruits throughout the world. It belongs to the family Rosaceae, subfamily Rosoideae. The cultivated strawberry (Fragaria $\times$ ananassa Duch.), a hybrid between (Fragaria virginiana $\times$ Fragaria chiloensis), obtained more than 300 years ago in Europe. Strawberry plants are perennial, stoloniferous herb, meaning that they spread via stolons or "runners". There are about 20 recognized species of strawberries in five chromosome group ( $\mathrm{x}=7)$ : ten diploids, four tetraploids, one pentaploid, one hexaploid and four octaploids
The experiment was conducted from September 2017 to February 2018 at Plant Tissue Culture Laboratory, Department of Fruit science, College of Horticulture and Forestry, Jhalrapatan City, Jhalawar to examine the effect of different combinations of plant growth regulators for in-vitro propagation of strawberry. The nodal segments were cultured on MS medium supplemented with different concentrations of shooting (BA, NAA, GA 3 , adenine sulphate and coconut water) hormones for direct regeneration. MS media supplemented with $2 \mathrm{ppm} \mathrm{BA}+0.2 \mathrm{ppm} \mathrm{NAA}+1 \mathrm{ppm}$ adenine sulphate took minimum days for sprouting (8.2 days) with highest sprouting percentage (92.59\%) and produced maximum $0.1 \mathrm{ppm} \mathrm{NAA}+1 \mathrm{ppm}$ adenine sulphate $+150 \mathrm{ml}$ coconut water produced the highest number of leaves (8.93) and maximum number of shoot (5.46) each explant.

(Staudt, 1999; Jiajun et al., 2005). The cultivated strawberry is an octaploid $(2 \mathrm{n}=8 \mathrm{x}=$ 56).

The strawberry fruits are rich of vitamin $\mathrm{C}, \mathrm{B}_{1}$, $\mathrm{B}_{2}$, protein, calcium, potassium, copper and then, most of the nutritious elements essential for human being (Nehra et al., 1994). Moreover, it has low-caloric carbohydrate, high fiber content and also good source of natural antioxidants including carotenoids, phenols and flavonoids.

Importing mother plants is expensive. Healthy stocks used for propagation through conventional methods are not available. The in-vitro culture of nodal cutting has been 
successful in the micro-propagation of strawberry plants (Karhu and Hakala, 2007). It was have an opinion that several plants can be produced within a year from a few mother plants by tissue culture technique (Boxus, 1983; Nehra et al., 1994). Propagation of strawberry is achieved either by runners or by in-vitro micro-propagation. Micro-propagation of strawberry from runners for beginning has been reported and may be refer to efficiently generate a large number of disease free plants (Boxus, 1974). Micro-propagated strawberry plant has been introduced to prevent most of the plant and soil transmissible diseases.

In the present examination a simple protocol has been developed to propagate strawberry through tissue culture methods from nodal segment using different growth regulators.

\section{Materials and Methods}

The experiment was conducted at Plant Tissue Culture Laboratory, Department of Fruit Science, College of Horticulture and Forestry, Jhalarapatan City, Jhalawar. The nodal segments of mature strawberry plant were used as explant that's collected from Protected Cultivation Unit Department of Vegetables Science, College of Horticulture \& Forestry, Jhalrapatan City, Jhalawar. Explants were washed first under running tap water for 20-25 min. Then they were rinsed with sterilized distilled water. Finally, explants were subjected to incision into appropriate sizes (around 1-1.5 cm long), and then transferred to the laminar hood where the processed explants were sterilized in $0.1 \% \mathrm{HgCl}_{2}$ with 2 drops of tween 20 for five minutes followed by three rinsing with sterile distilled water for 4 minutes each. Afterwards explants were resized by scalpels and forceps. Trace of water remaining on the surface of the explants was soaked with sterilized filter paper. Thus surface sterilization was completed and Node was cultured on MS basal medium supplemented along with the concentration of BAP, NAA, $\mathrm{GA}_{3}$, Adenine sulphate and Coconut water (Table 1). After mixing all stock solutions and growth regulators at appropriate volume, $3 \%$ sucrose was added. The $\mathrm{pH}$ of the medium was adjusted to 5.7-5.8 then and $0.8 \%$ agar was added and dissolved. The medium were dispensed in the glass bottles in a volume of $50 \mathrm{ml}$. Sterilization performed by autoclaving at $121^{\circ} \mathrm{C}$ for 20 minutes. About 3-4 weeks period was required for shoot proliferation. Subculture again for further multiple shoots induction. Regenerated multiple shoots were cut and individual shoots were placed in MS medium containing different concentrations of IBA and IAA for root induction. After rooting, hardening of the plantlets was carried out in a media consisting of a mixture of Coco peat, vermicompost, vermiculite were used in the plastic cups and transferred in culture room for hardening. After 1 week the hardened plantlets were planted in soil.

The tests were conducted under laboratory conditions. Observations was carried out using CRD with 5 explants were used per treatment and replicated three times.

\section{Results and Discussion}

In present study among all the concentrations and combinations of MS medium supplemented with BA, NAA, $\mathrm{GA}_{3}$ with or without additives (adenine sulphate and coconut water), and the highest per cent explants sprouted $(92.59 \%)$ was observed in the treatment MS medium+ 2 ppm BA+ 0.2 ppm NAA+ 1 ppm adenine sulphate $\left(\mathrm{T}_{2}\right)$. Landi and mezzeti (2006) stated that hormonal balance has a key role in regulation of morphological response from cultured explant. Similarly Landi and mezzeti (2006) also emphasized that cytokinin and auxin in appropriate ratio are required for efficient shoot regeneration. Thus the present results 
are in accordance of Ara et al., (2012) who found that $\mathrm{MS}+\mathrm{BAP}$ at $1.5 \mathrm{mg} / 1+$ kinetin at $0.5 \mathrm{mg} / 1$ were earliest for shoot initiation in strawberry. Moradi et al., (2011), Khierallah et al., (2014) and Karim et al., (2015) also reported rapid sprouting in strawberry using MS medium containing Kinetin or in combination with BAP and NAA.

The application of MS medium+ $2 \mathrm{ppm} \mathrm{BA}+$ 0.2 ppm NAA+ 1 ppm adenine sulphate treatment took minimum number of days for sprouting (8.2) days. It might be due to suitable amount of auxins and cytokinins and genetic makeup or physiological condition of the explants, which played an important role for early shoot initiation. Similar reduction in days for sprouting of strawberry explant due to MS medium supplemented with cytokinin was also reported by Diengngan et al., (2014). The promoting effect of BAP, NAA and $\mathrm{GA}_{3}$ at suitable concentration in micro-propagation of strawberry however had been reported earlier by Ara et al., (2012), Bhatt et al., (2012), Mohmoud and Kosar (2013) (Fig. 1).

The highest numbers of leaves obtained at MS medium +1 ppm BA +0.1 ppm NAA +1 ppm adenine sulphate $+150 \mathrm{ml}$ coconut water treatment (8.93) as compared to lowest number of leaves per explant obtained at control (3.20). The best shooting response and highest number of shoot per explant in MS medium containing cytokinin BAP (2 mg/l) and auxin NAA $(0.1 \mathrm{mg} / \mathrm{l})$ has been observe by Mohmoud and Kosar (2013), which confirm the present finding. These results are in accordance of Bhatt et al., (2012) who found that highest number of leaves in MS medium supplemented with BAP $(1.5 \mathrm{mg} / \mathrm{l})$ and Kinetin $(0.1 \mathrm{ppm})$ showed the best results when compared to other combinations after 30 days of incubation. The highest number of leaves in strawberry using MS medium containing BA and IBA. These results are also conformity with the previous results as reported by Ashrafuzzaman et al., (2013), Khierallah et al., (2014).

The maximum number of shoots (5.46) was obtained atMS medium +1 ppm $\mathrm{BA}+0.1$ ppm NAA +1 ppm adenine sulphate $+150 \mathrm{ml}$ coconut water $\left(\mathrm{T}_{3}\right)$.

Thus might be due to the high concentration of adenine sulphate with low concentration of BA and NAA produce significant number of shoots (Hasan et al., 2010). Similar results were reported by Ara et al., (2012) and Moradi et al., (2011) they described that cytokinin with optimum level may have induced more number of shoots, on the other hand high concentration of cytokinin reduced the number of micropropagated shoots.

Ashrafuzzaman et al., (2013) studied the effect of BAP on in-vitro multiplication of strawberry and observed that lower level of BAP $(0.5 \mathrm{mg} / \mathrm{l})$ was more effective for shoot proliferation as compared to 1.0 to $3.0 \mathrm{mg} / \mathrm{l}$ BAP. To support the present results Haddadi et al., (2010) has confirmed the importance of TDZ as a cytokinin to promote a high number and percentage of shoot formation in strawberry either alone or in combination with BAP. They stated that presence of TDZ and BAP broke the apical dominance and therefore shoot branching occurred.

The maximum length of shoot was recorded at $\mathrm{MS}$ medium $+2 \mathrm{ppm} \mathrm{BA}+0.2 \mathrm{ppm} \mathrm{NAA}+1$ ppm adenine sulphate treatment $(3.06 \mathrm{~cm})$ Hasan et al., (2010) observed the maximum length of shoot on adenine containing medium. According to him, high concentration of adenine sulphate with low concentration of BA and NAA may favour the significant increase in length of shoots. Ara et al., (2012) also reported the highest length of the shoot in the medium containing $\mathrm{GA}_{3}(0.5$ $\mathrm{mg} / \mathrm{l})$ and BAP (2 mg/l) which was to some explant consistent with the present findings. 
Fig.1 In-vitro propagation of strawberry (Fragaria $\times$ ananssa Duch.)
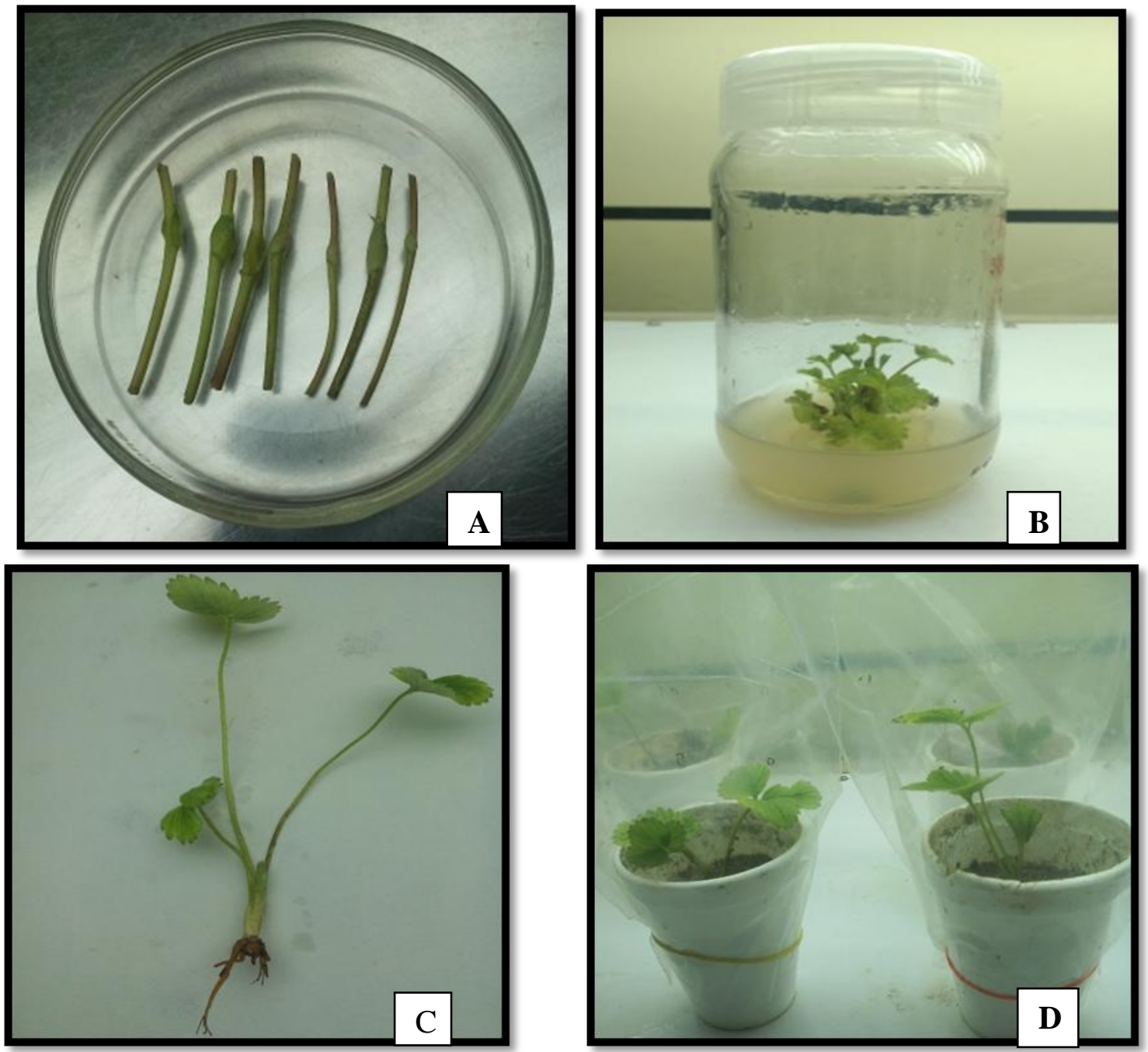

A. Nodal segment as explants, B. Shoot multiplication C. Rooting, D. Hardening

Table.1 Treatment combination for shoot proliferation in strawberry

\begin{tabular}{|c|c|c|}
\hline S. No. & $\begin{array}{l}\text { Treatment } \\
\text { Notation }\end{array}$ & Treatment combination \\
\hline 1. & $\mathrm{~T}_{0}$ & MS medium (control) \\
\hline 2. & $\mathrm{~T}_{1}$ & MS medium + 1 ppm BA + 0.1 ppm NAA \\
\hline 3. & $\mathrm{~T}_{2}$ & $\mathrm{MS}$ medium $+2 \mathrm{ppm} \mathrm{BA}+0.2 \mathrm{ppm} \mathrm{NAA}+1 \mathrm{ppm}$ Adenine sulphate \\
\hline 4. & $T_{3}$ & $\begin{array}{l}\text { MS medium + } 1 \text { ppm BA + } 0.1 \text { ppm NAA + } 1 \text { ppm Adenine sulphate }+150 \mathrm{ml} \\
\text { Coconut water }\end{array}$ \\
\hline 5. & $\mathrm{~T}_{4}$ & MS medium + $1 \mathrm{ppm} \mathrm{BA}+0.1 \mathrm{ppm} \mathrm{NAA}+1 \mathrm{ppm} \mathrm{GA}+150 \mathrm{ml}$ Coconut water \\
\hline 6. & $\mathrm{~T}_{5}$ & MS medium $+2 \mathrm{ppm} \mathrm{BA}+0.1 \mathrm{ppm} \mathrm{NAA}+1 \mathrm{ppm} \mathrm{GA}+150 \mathrm{ml}$ Coconut water \\
\hline 7. & $\mathrm{~T}_{6}$ & $\mathrm{MS}$ medium $+2 \mathrm{ppm} \mathrm{BA}+0.2 \mathrm{ppm} \mathrm{NAA}+1 \mathrm{ppm} \mathrm{GA}+150 \mathrm{ml}$ Coconut water \\
\hline 8. & $\mathrm{~T}_{7}$ & MS medium $+3 \mathrm{ppm} \mathrm{BA}+0.3 \mathrm{ppm} \mathrm{NAA}+1 \mathrm{ppm} \mathrm{GA}+150 \mathrm{ml}$ Coconut water \\
\hline
\end{tabular}


Table.2 Effect of growth regulators on shoot proliferation of strawberry (Fragaria $\times$ ananassa Duch.). Data were taken 4-6 weeks after culture

\begin{tabular}{|c|c|c|c|c|c|}
\hline Treatments & $\begin{array}{c}\text { Per cent } \\
\text { explants } \\
\text { sprouted }\end{array}$ & $\begin{array}{c}\text { Number of } \\
\text { days required } \\
\text { for sprouting }\end{array}$ & $\begin{array}{c}\text { Number of } \\
\text { leaves } \\
\text { /explant }\end{array}$ & $\begin{array}{c}\text { Number of } \\
\text { shoots /explant }\end{array}$ & $\begin{array}{c}\text { Length of } \\
\text { shoot (cm) }\end{array}$ \\
\hline $\mathrm{T}_{\mathbf{0}}$ & 45.55 & 14.00 & 3.20 & 1.66 & 1.48 \\
\hline $\mathrm{T}_{1}$ & 74.44 & 11.00 & 4.26 & 2.26 & 1.80 \\
\hline $\mathrm{T}_{2}$ & 92.59 & 8.20 & 6.40 & 3.66 & 3.06 \\
\hline $\mathrm{T}_{3}$ & 89.99 & 9.00 & 8.93 & 5.46 & 2.22 \\
\hline $\mathrm{T}_{4}$ & 79.99 & 10.00 & 5.40 & 2.93 & 2.32 \\
\hline $\mathrm{T}_{5}$ & 85.55 & 12.53 & 5.66 & 3.00 & 2.32 \\
\hline $\mathrm{T}_{6}$ & 87.4 & 9.46 & 5.46 & 2.86 & 2.80 \\
\hline $\mathrm{T}_{7}$ & 69.99 & 13.00 & 5.86 & 3.13 & 2.14 \\
\hline CD at $\mathbf{5} \%$ & 2.22 & 0.65 & 2.42 & 0.57 & 0.28 \\
\hline SEm $\mathbf{m}$ & 1.04 & 0.30 & 1.14 & 0.27 & 0.13 \\
\hline
\end{tabular}

Similarly the maximum length of shoot in strawberry using MS medium containing Kinetin, BAP, NAA and $\mathrm{GA}_{3}$ was also reported by Moradi et al., (2011), Bhatt et al., (2012), Ashrafuzzaman et al., (2013) and Bhandari et al., (2015) in strawberry (Table 2).

Plant tissue culture is the primary branch of plant biotechnology. It offers the recovery of disease resistant, salinity resistant, stress tolerance of high yielding varieties. Nevertheless, to elucidate in-vitro propagation of strawberry (Fragaira $\times$ ananassa Duch.) with a view to determine the most suitable medium compositions for shoot proliferation in-vitro from nodal segments. The explants cultured on MS media containing 2 ppm BA+ $0.2 \mathrm{ppm} \mathrm{NAA}+1 \mathrm{ppm}$ adenine sulphate using nodal segment as explants took less time for sprouting, highest sprouting percentage, maximum length of shoots and MS medium containing 1 ppm $\mathrm{BA}+0.1$ ppm NAA +1 ppm adenine sulphate $+150 \mathrm{ml}$ coconut water produce maximum number of shoots and highest number of leaves per explants. Invitro propagated plantlets were successfully established in soil. The successful protocol could be useful for successful proliferation of plants in strawberry.

\section{Acknowledgement}

Words fail to express the sincere and deep sense of reverence to Plant Tissue Culture Laboratory, Department of Fruit Science, College of College of Horticulture and forestry, Jhalawar.

\section{References}

Ara, T., Karim, R., Karim, M.R., Ahmad, S., Islam, R., Hossain, M., (2012). Effects of different hormones on in-vitro regeneration of strawberry (Fragaria $\times$ ananssa Duch.). Int. J.Biosci., Vol. 2, No. 10(1): 86-92.

Ashrafuzzaman, M., Faisal, S.M., Yadav, D., Khanam, D., and Raihan, F., (2013). Micropropagation of strawberry (Fragaria $\times$ ananassa) through runner culture. Bangladesh J. Agril. Res., 38(3): 467-472.

Bhandari, M., and Roy, S.K., (2015). Standardization and establishment of an efficient protocol for in-vitro multiplication of Strawberry plant and its 
genetic stability testing. International Journal of Pharmaceutical Science Invention, Volume 4(8): 07-12.

Bhatt, R.P., Kheroda, D.M., Jayaluxmi, H., Sophia, I. and Prajani, S., (2012). Effect of plant growth regulators on establishment and growth of strawberry (Fragaria $\times$ ananassa Duch.) var. Chandler in vitro. Agricultural Science Research Journal, 2(12): 623-632

Boxus, P.H., (1974). The production of strawberry plants by in-vitro micropropagation. Journal of Horticultural Science \& Biotechnology, 49(3): 209-210.

Boxus, P.H., (1983). Commercial production of strawberry plants produced by meristem culture and micro propagation. Colloques Scientifiques Hort. Abstr., 53: 283-322.

Diengngan, S. and Murthy, B.N.S., (2014). Influence of plant growth promoting substances in micro-propagation of strawberry cv. Festival. The Bioscan, 9(4): 1491-1493.

Haddadi, F., and Aziz, M.A., Saleh, G., Rashid, A.A. and Kamaladini, H., (2010). Micropropagation of strawberry cv. Camarosa: prolific shoot regeneration from In vitro shoot tips using thidiazuron with N6benzylamino-purine. Hort. Science, 45(3): 453-456.

Hasan, M.N., Nigar, S., Rabbi, M.A.K., Mizan, S.B. and Rahman, M.S., (2010). Micropropagation of strawberry (Fragaria $\times$ ananassa Duch.). Int. J. Sustain. Crop prod., 5(4): 36-41.

Jiajun, L., Yubua, L., Guodong D., Hanping, D., Mingqin, D., (2005). A natural pentaploid strawberry genotype from the Changbaimountains in Northeast China. Hort. Science, 40: 1194-1195.
Karhu, S. and Hakala, K., (2002). Micropropagated strawberries on the field. ISHS Acta Horticulture, 2: 182.

Karim, R., Ahmed, F., Roy, U.K., Ara, T., Islam, R., and Hossain, M., (2015).Varietal improvement of strawberry (Fragaria $\times$ ananassa Dutch.) through somaclonal variation using in vitro techniques. J. Agr. Sci. Tech., Vol. 17: 977-986.

Khierallah, H.S.M., Ahmad, R.A.H., (2014). Effect of explant type and benzyl adenine on culture initiation and multiplication of three strawberry's cultivars. Al-Furat Journal of Agricultural Sciences, 6(4): 113.

Landi, L. and Mezzett, B., (2006). TDZ, auxin and genotype effects on leaf organogenesis in Fragaria. Plant Cell Reports, 25(4): 281-288.

Mahmoud, O. and Kosar, M., (2013). Regeneration and histological of plants derived from leaf explants in vitro culture of strawberry. Int. J. Agric. Crop Sci., 5(9): 943-950.

Moradi, K., Otroshy, M. and Azimi, M.R. (2011). Micropropagation of strawberry by multiple shoots regeneration tissue cultures. J. Agric. Tech., 7(6): 1755-1763.

Nehra, N.S., Kartha, K.K., Stushnoff and Giles, K.L., (1994). Effect of in-vitro propagation methods on field performance of strawberry cultivars. Euphytiea, 76: 107-15.

Staudt, G., (1999). Systematics and Geographical Distribution of the American Strawberry Species: Taxonomic Studies in Genus Fragaria (Rosaceae: Potentilleae). University of California Publications in Botany, Berkeley, CA, 81: 122.

\section{How to cite this article:}

Sunita Jhajhra, L.K. Dashora, Jitendra Singh, P. Bhatnagar, Ashok Kumar and Arya, C.K. 2018. Invitro Propagation of Strawberry (Fragaria $\times$ ananassa Duch.). Int.J.Curr.Microbiol.App.Sci. 7(10): 3030-3035. doi: https://doi.org/10.20546/ijcmas.2018.710.353 